Note / Nota

\title{
LONG-LIFE TOMATO CULTIVARS GROWING UNDER THE HYDROPONIC NUTRIENT FILM TECHNIQUE
}

\author{
Ronan Gualberto ${ }^{1 *}$; Paulo Sérgio Rabelo de Oliveira1; Francisco Vilela Resende² \\ ${ }^{1}$ Depto. de Fitotecnia - Unimar/FCA, C.P. 554 - CEP: 17525-902 - Marília, SP. \\ ${ }^{2}$ Embrapa Hortaliças - C.P. 208 - CEP: 70359-970 - Brasília, DF. \\ ${ }^{*}$ Corresponding author <ronangual@uol.com.br>
}

ABSTRACT: Farmers are interested in hydroponic tomato cultivation because of the high demand of high quality products by the consumers. Three trials here carried out under greenhouse conditions in Marília, SP, Brazil, using the hydroponic nutrient film technique, in order to evaluate yield and quality of long-life salad tomato (Lycopersicon esculentum) varieties, during 1998 and 1999. Four varieties (Carmen, Diva, Graziela, and Vita) were tested using a randomized block design, with six replications. The variety $\mathrm{x}$ crop season interaction effect was significant, meaning that varieties have distinct performances during the different cropping seasons. The Vita variety presented commercial valid yield, with mean fruit weights higher than the other varieties.

Key words: Lycopersicon esculentum, hidroponic crops, greenhouse, fresh-market tomato

\section{PRODUTIVIDADE DE CULTIVARES DE TOMATEIRO TIPO LONGA-VIDA NO SISTEMA HIDROPÔNICO "NFT"}

\begin{abstract}
RESUMO: Devido à expansão da demanda por produtos nobres e de alta qualidade pelos consumidores mais exigentes e de maior poder aquisitivo, o cultivo de tomateiro em sistema hidropônico tem despertado interesse de alguns produtores. Com o objetivo de avaliar a produção e qualidade de cultivares de tomateiro (Lycopersicon esculentum) longa vida do grupo salada, em ambiente protegido, no sistema hidropônico "NFT", foram conduzidos três experimentos em Marília - SP, no período de 1998/1999. Foram utilizadas quatro cultivares (Carmen, Diva, Graziela e Vita), no delineamento experimental blocos ao acaso, com seis repetições. O efeito da interação entre cultivares e épocas de plantio foi marcante, indicando que as cultivares não demonstraram um comportamento concordante nos três experimentos. 'Vita' foi estatisticamente superior às demais cultivares nas características produtividade comerciável e peso médio de frutos.

Palavras-chave: Lycopersicon esculentum, hidroponia, casa-de-vegetação, tomate de mesa
\end{abstract}

\section{INTRODUCTION}

In Brazil, the tomato production for consumption as fresh fruit was significantly altered because of the technological changes that took place in the last decade, surch as the development of several new varieties, like the new generation of hybrids developed for salad, which are replacing the traditional large and fleshy Japanese varieties (FNP Consultoria e Comércio, 1998).

The cultivation of long-life tomato varieties has also expanded more than expected, particularly in the Southern and Southeastern regions of Brazil. Since they were introduced in Brazil, the long-life tomatoes have increased their sharing in the fresh market and are estimated to account for about $70 \%$ of the whole market (Della Vecchia \& Koch, 2000).

The tomato crops have become less resistant to diseases, pests, and adverse environmental conditions as a result of the long-term selection process imposed in order to improve fruit productivity and quality. Therefore, the tomato crops became very dependent on the intensive use of pesticides when grown in open field.
In order to reduce this heavy use of pesticides and improve productivity, greenhouse cultivation has expanded since it allowed a better control of the environmental conditions. In fact, greenhouse cultivation has improved tomato productivity and reduced pesticide use, but it also caused soil salinization resulting from the heavy application of fertilizers, besides have driven to the appearance of diseases and soil pests, such as nematodes, which are difficult to control.

In order to solve these problems, hydroponic systems started to be developed in Brazil, once they were already widely accepted in Japan and The Netherlands. Hydroponic systems provide better yield scheduling, avoiding crop rotation; better fruit quality; better crop handling; and better control over the environmental conditions and the nutritional needs (Martinez, 1999). On the other hand, hydroponic systems demand high technology and are not cost effective yet.

Hydroponic products attract consumers due to their better appearance. In addition, the rigid control over nutrient supplies enhances the longevity of the product for both, shelf and refrigerated conditions, when 
compared to conventional systems of cultivation (Garcia et al., 1997). According to these authors, this is particularly important for highly perishable vegetables, such as tomatoes.

Hydroponic systems are classified in Brazil in either open or closed. In the open system, which is an intermittent system, the nutrient solution either flows through cultivation tubes or is deposited onto the cultivation substrates, and the exceeding amounts return to the catchment tank. In the closed system, which is a static-intermittent system, the nutrient solution is injected only once per irrigation cycle and the remaining solution is not returned to the catchment tank (Resh, 1997). For tomatoes, there has been a trend to adopt the Nutrient Film Technique (NFT) in Brazil. It consists of a circulating film of nutrient solution through the root system of the growing plants, with a preset application frequency and timing (Moraes \& Furlani, 1999). However, NFT requires high level technical skills for the users, mainly to adjust nutrient solution needs according to the different growing phases of the plant (Makishima \& Miranda, 1995).

In hydroponics it is possible to use both, determinate and indeterminate varieties, which are chosen based on their cycles, as done in soil cultivation systems. For tomato hydroponics, the varieties mostly used are the long-life indeterminate ones (Martinez, 1997).

Vegetable production in greenhouse requires well adapted varieties, with an optimum crop yield and high quality fruits. However, in Brazil, there is not enough information about the fitness/adaptation of such varieties to the NFT. Therefore, the aim of this research was to evaluate the performance of long-life tomato varieties growing in greenhouse under NFT hydroponics, in order to enhance crop yield and fruit quality.

\section{MATERIAL AND METHODS}

Three trials were carried out in Marília, SP, Brazil (22 $12^{\prime} 50^{\prime \prime} \mathrm{S}$; $49^{\circ} 56^{\prime} 45^{\prime \prime} \mathrm{W}$; and altitude of $610 \mathrm{~m}$ ), using four long-life tomato varieties from the Salad Group (Carmen, Diva, Graziela and Vita). The NFT hydroponic system was installed in a greenhouse $(21 \mathrm{~m} \times 28 \mathrm{~m} \times 4$ $\mathrm{m})$ having a metallic frame, which was covered with an UV- light resistant polyethylene plastic (150 $\mu \mathrm{m}$ thickness) and shielded laterally with a plastic screen which provided $50 \%$ of shading. The first, second, and third trials were carried out from February to July, 1998; from July to December, 1998; and from March to August, 1999, respectively.

Randomized blocks were adopted as experimental design, with six replications. Each experimental unit comprehended eight plants in row, and the measurements were performed on four of them. The spacing between rows was $1.2 \mathrm{~m}$ and within plants 0.25 $\mathrm{m}$. Seedlings were grown in foam cubes, which were transplanted to a nursery just after emergence and were maintained there for about 25 days, supplying the nutrient solution periodically. After this, seedlings were definitively transplanted to PVC tubes (with trapezoid cross section), having $0,05 \mathrm{~m}$ wholes in diameter at each interval of 0.25 $\mathrm{m}$. Individual pumps were installed in each furrow in order to supply nutrient solution for the plants (Figure 1). The used nutrient solution was adapted from Resh (1997), and was made up of $236.3 \mathrm{mg}$ of $\mathrm{N} ; 39.0 \mathrm{mg}$ of $\mathrm{P} ; 224.9$ $\mathrm{mg}$ of $\mathrm{K} ; 228.0 \mathrm{mg}$ of $\mathrm{Ca} ; 33.7 \mathrm{mg}$ of $\mathrm{Mg} ; 46.3 \mathrm{mg}$ of $\mathrm{S}$; $0.24 \mathrm{mg}$ of $\mathrm{B} ; 0.02 \mathrm{mg}$ of $\mathrm{Cu} ; 5.0 \mathrm{mg}$ of $\mathrm{Fe} ; 0.23 \mathrm{mg}$ of $\mathrm{Mn} ; 0.03 \mathrm{mg}$ of $\mathrm{Mo}$; and $0.05 \mathrm{mg}$ of $\mathrm{Zn}$ per liter of solution.

The electrical conductivity (EC) was kept at 1.5 - 2.0 and at $2.5-3.5 \mathrm{mS} \mathrm{cm}^{-1}$ in the nursery and greenhouse, respectively, and varied according to the development stage of the plants. The $\mathrm{pH}$ values ranged from 5.5 to 6.5 . EC and $\mathrm{pH}$, were monitored daily and adjusted when needed. Whenever EC felt below the above cited range, stock nutrient solution was added; and whenever EC was above this range, water was added. The solution $\mathrm{pH}$ was adjusted by adding either $1.0 \mathrm{~mol}$ $\mathrm{L}^{-1} \mathrm{NaOH}$ or $1.0 \mathrm{~mol} \mathrm{~L}^{-1} \mathrm{HCl}$. Moreover, nutrient solution was added daily to avoid depletion by absorption and evapotranspiration, but always respecting the EC range. The nutrient solution was totally replaced every 20 to 30 days.

The pumping of the nutrient solution from the catchment tank was performed automatically during nursery and growing stages, starting at 7:00 a.m., maintaining an intermittent nutrient flow, working for 20 min. and stopping for $10 \mathrm{~min}$., during the production phase, until 6:00 p.m.. At night, the system was activated twice, at 11:00 p.m. and 3:00 a.m., working for $20 \mathrm{~min}$. only.

Tomato secondary stems were trimmed out and the main stem was supported by a nylon string. When the plants reached $2.0 \mathrm{~m}$, their apex was also trimmed. Pesticides were applied whenever needed in order to

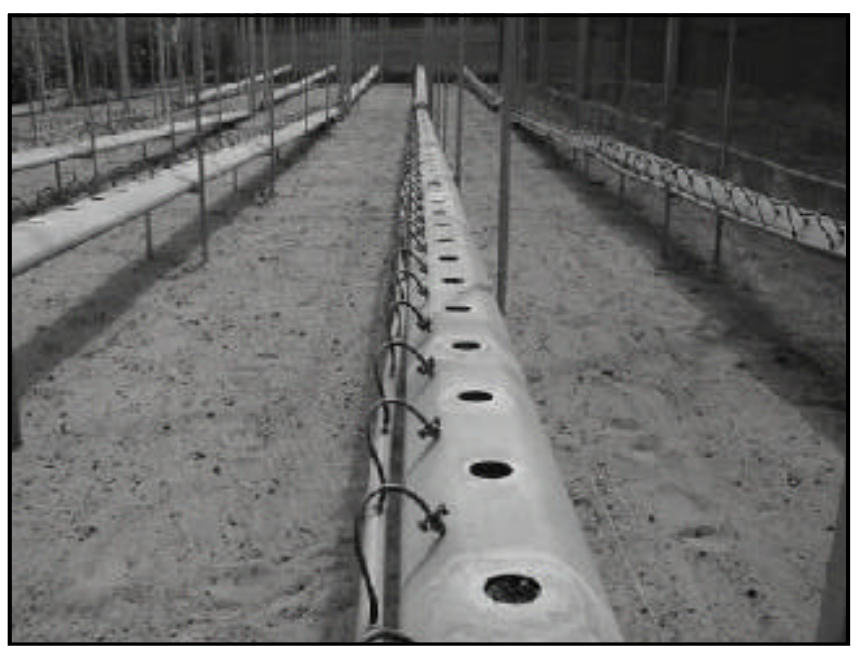

Figure 1 - Details of the NFT hydroponics, showing the PVC tubes and the individual pumps. 
control insects and plant diseases. Fruit harvest was performed weekly. The total and the commercial (fruits with transversal diameter $\geq 50 \mathrm{~mm}$ ) yields were evaluated, calculating also the mean weights for the commercial fruits.

\section{RESULTS AND DISCUSSION}

Total and commercial yields were different $(P<$ 0.01 ) among the varieties and cropping seasons. Interactions were also significant, indicating that the performance of the tested varieties was affected by the cropping season.

The mean values for all evaluated parameters were not different for the first (February to July/1998) and the third (March to August/1999) cropping seasons (Table 1). Mean values of these seasons were, however, higher than those of the second cropping season (July to December/1998). This was likely due to the high temperatures during the second period. Sometimes, the air in the greenhouse and the nutrient solution reached temperatures around $30^{\circ} \mathrm{C}$ or even more. Nutrient solution temperature above $30^{\circ} \mathrm{C}$ can greatly affect the yield potential for fruits, since it results in high oxygen concentration in the solution and causes death of roots (Jones Jr., 1983; Moraes, 1997; Resh, 1997).

The total yield for the Carmen and Vita varieties was higher for all seasons. Vita (97.8\%), however, had always better performance than Carmen (93.2\%) in relation to commercial yield. In fact, the most important trait to evaluate tomato fruit performance is the commercial yield. In addition, Vita was the oney variety to present commercial fruit mean weights higher than the general mean value $(128.90 \mathrm{~g})$ obtained for all cropping seasons. Fruit weights is the best way to express fruit size.

The genotype-environment interaction was also observed through the changes in variety performance during the different cropping seasons (Table 1). For example, Diva, during the second cropping season, was the only one with mean values, both for yield and weight, higher than those found for the third cropping season, during which the performance for all varieties was the best. This can only be explained by the cropping season effect outweighing the variety effect. Genotype $x$ environment interaction was also found to affect tomato yield by other scientists (Martins, 1983; Reis et al., 1991; Grodzky \& Brenner, 1992; Hamerschmidt \& Freitas, 1992).

The good performance of the Vita variety in this experiment, both for yield and mean weight, is in agreement with the findings of Gualberto et al. (1998, 2000). These authors compared the performance of the same varieties growing in greenhouse and in the open field in their first work, and evaluated the performance of six salad varieties (including those considered here) under nine distinct growing systems (either open field or
Table 1 - Total and commercial (fruits with transversal diameter $\geq 50 \mathrm{~mm}$ ) yields, and commercial mean weights form tomatoes produced by NFT hydroponics. Marília-SP, Brazil. 1998/1999.

\begin{tabular}{|c|c|c|c|c|}
\hline \multicolumn{5}{|c|}{ Crop Season } \\
\hline & $02-07 / 98$ & $07-12 / 98$ & $03-08 / 99$ & Means \\
\hline \multicolumn{5}{|c|}{ Total fruit yield } \\
\hline \multicolumn{5}{|c|}{ 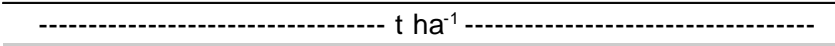 } \\
\hline \multicolumn{5}{|l|}{ Varietie } \\
\hline Carm & $86.13 \mathrm{Ab}$ & 60.4 & $5 \mathrm{Aa}$ & $83.28 \mathrm{~A}$ \\
\hline va & $\mathrm{Aa}$ & 54.5 & $3 \mathrm{Cb}$ & $58.73 \mathrm{C}$ \\
\hline raz & $\mathrm{Aa}$ & 53.5 & $\mathrm{Ba}$ & $71.49 \mathrm{~B}$ \\
\hline Vita & $85.56 \mathrm{Ab}$ & 78.8 & $5 \mathrm{Aa}$ & $91.19 \mathrm{~A}$ \\
\hline ean & $81.34 \mathrm{a}$ & $61.84 \mathrm{~b}$ & $4 \mathrm{a}$ & 76.17 \\
\hline \multicolumn{5}{|c|}{ Commercial fruit yield } \\
\hline \multicolumn{5}{|c|}{ 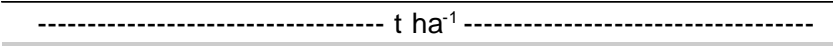 } \\
\hline armen & $78.23 \mathrm{Ab}$ & $56.55 \mathrm{Bc}$ & $99.61 \mathrm{Aa}$ & $78.13 \mathrm{~B}$ \\
\hline iva & $71.05 \mathrm{Aa}$ & 51.3 & $45.43 \mathrm{Cb}$ & $55.94 \mathrm{D}$ \\
\hline Graziela & $75.59 \mathrm{Aa}$ & 48.3 & $77.60 \mathrm{Ba}$ & $67.18 \mathrm{C}$ \\
\hline /ita & $83.69 \mathrm{Ab}$ & 76.6 & 107.28 Aa & $89.22 \mathrm{~A}$ \\
\hline ean & $77.14 \mathrm{a}$ & $58.23 \mathrm{~b}$ & $82.48 \mathrm{a}$ & 72.62 \\
\hline \multicolumn{5}{|c|}{ Commercial fruit mean weight } \\
\hline \multicolumn{5}{|c|}{ 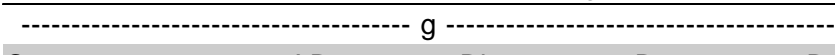 } \\
\hline Jarmen & $126.58 \mathrm{ABa}$ & 113.6 & $125.77 \mathrm{Ba}$ & $122.00 \mathrm{~B}$ \\
\hline iva & $126.19 \mathrm{ABa}$ & $123.53 \mathrm{Ba}$ & $122.44 \mathrm{Ba}$ & $124.10 \mathrm{~B}$ \\
\hline Ġraziela & $121.40 \mathrm{Bb}$ & $119.64 \mathrm{Bb}$ & $130.14 \mathrm{Ba}$ & $123.70 \mathrm{~B}$ \\
\hline ita & 137.29 Ab & $137.91 \mathrm{Ab}$ & $162.30 \mathrm{Aa}$ & $145.80 \mathrm{~A}$ \\
\hline lean & $127.87 \mathrm{a}$ & $123.69 \mathrm{~b}$ & $135.16 \mathrm{a}$ & 128.90 \\
\hline
\end{tabular}

Mean values followed by the same capital letters on the columns and small letters on the rows are not different according to the Tukey test at $5 \%$.

greenhouse, under conventional and hydroponic systems) in their later work. They also concluded that Vita had the best performance in the tested growing systems, with less interaction effects.

The mean values for the commercial yield and fruit weight found in the present study were lower than those for the same varieties growing either in greenhouse (conventional system) or open field (Gualberto et al., 1998). The lower yields may be partially due to a failure in controlling the nutrient solution supply, since it was performed according Resh (1997), a procedure suggested for tropical countries, not adjusted for the particular conditions of Brazil. According to Makishima \& Miranda (1995), one of the major problems of using the NFT hydroponics for tomatoes is that it requires highly specialized technical support in order to properly replenish the nutrient solution in all the growing phases of the crop.

\section{REFERENCES}

DELLA VECCHIA, P.T.; KOCH, P.S. Tomate longa vida: O que são, como foram desenvolvidos? Horticultura Brasileira, Brasília, v.18, p.3-4, 2000. FNP CONSULTORIA E COMÉRCIO. Agrianual 99. São Paulo, 1998. p.489497.

GARCIA, I.P.; MARQUES, M.C.; SILVA, V.T.A. Olericultura: saladas menos convencionais. In: FNP CONSULTORIA E COMÉRCIO. Agrianual-98, São Paulo, 1997. p.31-36. 
GRODZKY, L.; BRENNER, N.L. Produção de tomate sob influência de diferentes plásticos na região de Curitiba. Horticultura Brasileira, v.10, p.55, 1992. (Resumos).

GUALBERTO, R.; BRAZ, L.T.; BANZATTO, D.A. Adaptabilidade e estabilidade fenotípica de genótipos de tomate sob diferentes condições de ambiente. Horticultura Brasileira, v.18, p.644-645, 2000.

GUALBERTO, R.; RESENDE, F.V.; GUIMARÃES, A.M.; AMBRÓSIO, C.P. Comportamento de cultivares de tomate do grupo salada, tipo longa-vida, cultivados em ambiente protegido e a campo aberto. Unimar Ciências, v.7, p.133-138, 1998

HAMERSCHMIDT, I.; FREITAS, A.N. Evolução da plasticultura no Estado do Paraná. Horticultura Brasileira, v.10, p.57, 1992. (Resumos).

JONES Jr., J.B. A guide for the hydroponic and soilless culture grower. Portland: Timber Press, 1983. 124p.

MAKISHIMA, N.; MIRANDA, J.E.C. Cultivo do tomate. Brasília: EMBRAPA, CNPHortaliças, 1995. 22p. (Instruções Técnicas, 11).

MARTINEZ, H.P. O uso do cultivo hidropônico de plantas em pesquisa. 2.ed. Viçosa: UFV, 1999. 47p. (Cadernos didáticos, 1).

MARTINEZ, P.F. Sistemas de lana de roca: producción de tomates pimentos. In: CONFERENCIA INTERNACIONAL DE HIDROPONIA COMERCIAL, Lima, 1997. Lima: UNALM, 1997. p.67-78.
MARTINS, G. Comportamento de cultivares de tomateiro (Lycopersicon esculentum Mill) nas condições de trópico-úmido. Piracicaba, 1983. 72p. Dissertação (Mestrado) - Escola Superior de Agricultura "Luiz de Queiroz", Universidade de São Paulo.

MORAES, C.A.G.; FURLANI, P.R. Cultivo de hortaliças de frutos em hidroponia em ambiente protegido. Informe Agropecuário, v.20, p.105-113, 1999.

MORAES, C.A.G. Hidroponia: como cultivar tomates em sistema NFT (técnica de fluxo laminar de nutrientes). Jundiaí: DISK, 1997. 141p.

REIS, N.V.B.; HORINO, Y.; OLIVEIRA, C.A.S.; BOITEUX, L.S. Influência dos parâmetros agrometereológicos sobre a produção de nove genótipos de tomate plantados a céu aberto e sob proteção de estufas plásticas. Horticultura Brasileira, v.9, p.55, 1991

RESH, H.M. Cultivos hidroponicos: nuevas técnicas de producción. 4.ed. Madrid: Mundi-Prensa, 1997. 378p.

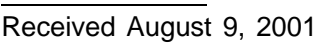

